\title{
The Nature and History of the Catholic Charismatic Renewal in Canada
}

\section{James Hanrahan}

Volume 50, numéro 1, 1983

Bilan de l'histoire religieuse au Canada

Canadian Catholic History: A survey

URI : https://id.erudit.org/iderudit/1007048ar

DOI : https://doi.org/10.7202/1007048ar

Aller au sommaire du numéro

Éditeur(s)

Les Éditions Historia Ecclesiæ Catholicæ Canadensis Inc.

ISSN

0318-6172 (imprimé)

1927-7067 (numérique)

Découvrir la revue

Citer cet article

Hanrahan, J. (1983). The Nature and History of the Catholic Charismatic

Renewal in Canada. Sessions d'étude - Société canadienne d'histoire de l'Église catholique, 50(1), 307-324. https://doi.org/10.7202/1007048ar

Tous droits réservés @ Les Éditions Historia Ecclesiæ Catholicæ Canadensis Inc., 1983
Ce document est protégé par la loi sur le droit d'auteur. L'utilisation des services d'Érudit (y compris la reproduction) est assujettie à sa politique d'utilisation que vous pouvez consulter en ligne.

https://apropos.erudit.org/fr/usagers/politique-dutilisation/ 


\title{
The Nature and History of the Catholic Charismatic Renewal in Canada
}

\author{
by James HanRahan, C.S.B. \\ St. Thomas More College, Saskatoon
}

In approaching this subject I am acutely aware of certain difficulties. There is, first, the intrinsic difficulty of writing about a movement of the Holy Spirit. After all, we have the word of Jesus himself:

The Wind blows wherever it pleases; you hear its sound, but you cannot tell where 'it comes from or where it is going. That is how it is with all who are born of the Spirit. (John 3:8)

Second, there is the difficulty, in treating of a development as recent as the charismatic renewal, of finding the needed perspective. One may look, say, at the spirituality of the seventeenth century and have some confidence that one can see the movement of the Spirit through several generations; but here we are looking only at the past fifteen years. Third, it must be noted that our subject is not located in one place, as, say, Ste. Anne de Beaupré, nor can we draw on any clearly defined body of material. The renewal spans the country and is largely unrecorded except in the memories of those involved. Fourth, I have a special difficulty in that I must write as one who has been and is still actively involved. I know that this places particular demands on me to exercise care in using evidence and in presenting my analysis. At the same time, I think it can also be seen as an advantage; one not involved could also find problems. ${ }^{1}$

\footnotetext{
${ }^{1}$ For an interesting discussion of some of the problems facing a researcher not involved in the renewal, see John Thompson, "Social Processes Related to Revivifying Religious forms within an institutional context: A Case Study of Charismatic Renewal Among Roman Catholics in Southern California", unpublished Ph. D. thesis, University of California, Santa Barbara, 1977, Appendix A, pp. 448-466.
} 
What we are looking at is the charismatic renewal as it has developed in the Catholic Church in Canada. The background of this may be found in the Pentecostal Movement, which is generally seen as having started on January 1, 1901, with an experience of the power of the Holy Spirit in a bible school in Topeka, Kansas, conducted by Rev. Charles F. Parham. ${ }^{2}$ A closer background is found in the NeoPentecostal or Charismatic Movement that grew up in many of the main-line Protestant Churches after starting in the Anglican Church in Van Nuys, California in 1960. ${ }^{3}$ Both of these movements existed in Canada before developments in the Catholic Church began. ${ }^{4}$ The Catholic Charismatic renewal started in the United States at a prayer and study weekend held at Duquesne University in Pittsburgh in February, 1967. It spread almost at once to Notre Dame University and quickly then, more broadly. ${ }^{5}$

The beginning of the charismatic renewal in the Catholic Church in Canada can probably best be said to have taken place in Combermere, Ontario, on August 20-21, 1968. ${ }^{6}$ Certainly there were individual

\footnotetext{
${ }^{2}$ Various other dates have been proposed. See Nil Bloch-Hoell, The Pentecostal Movement: Its Origin, Development and Distinctive Character, Olso: Universitets-forlaget, c 1964 , pp. 18-29.

${ }^{3}$ Richard Quebedeaux, The New Charismatics: The Origins, Development and Significance of Neo-Pentecostalism, Garden City, Doubleday, 1976, pp. 54-63. W.J. Hollenweger, The Pentecostals: The Charismatic Movement in the Churches, Minneapolis, Augsburg Publishing House, 1972, pp. 4-6.

${ }^{4}$ On Canadian Pentecostalism see Quebedeaux, New Charismatics, 45, and BlockHoell, Pentecostal Movement, $52 \mathrm{n}$. Neo-Pentecostalism started among Anglicans by 1962; see Al Reimers, God's Country: Charismatic Renewal, Toronto, G.R. Welch, 1979, p. 23.

${ }^{5}$ Edward D. O'Connor, The Pentecostal Movement in the Catholic Church, Notre Dame, Ave Maria Press, 1971, gives an account of the origins and spread of the renewal in its first few years. Kevin and Dorothy Ranaghan, Catholic Pentecostals, Paramus, Paulist Press, 1969, give more details on the Duquesne weekend, as do Patti Gallagher, "Are You Ready", and Paul and Mary Ann Gray, "God Breaks In", in Ralph Martin, comp., The Spirit and the Church: A Personal and Documentary Record of the Charismatic Renewal, and the Ways It Is Bursting to Life in the Catholic Church, New York, Paulist Press, 1976, pp. 4-10 and 11-20.

${ }^{6} \mathrm{My}$ information concerning this and the whole development at Madonna House comes from conversations I had there with Fathers Jim Duffy and Bob Pelton, Jean Fox and others, on July 13, 1982. I am grateful to them for their kindness and openness. I should say here at the beginning, in reference to them and to others with whom I talked, that any errors in my presentation should be attributed to me and not to those who were so generous in sharing their memories with me. Slightly different dates have been given elsewhere. A paper prepared for the third anniversary of the Regina prayer group, mentions August 22, 1968; a copy of this is included among notes on the early years of the Regina group which were kindly loaned to me by Adrian Popovici, now of Saskatoon. Father John Callahan, in remarks quoted in Reimers, God's Country, 71 , says the visitors spent three days there.
} 
Canadian Catholics who had experienced the power of the Spirit in the renewal before that time, ${ }^{7}$ but this seems to have been the first group experience which was to lead to further developments. For those two days a number of people from Ann Arbor, Michigan, including Steve Clark and Jim Cavnar, visited Madonna House in Combermere. ${ }^{8}$ They spoke about the action of the Holy Spirit in the United States as they had witnessed and shared in it since early 1967, and they prayed over many in the Combermere community.

Catherine Doherty, the remarkable woman who was the principal foundress of Madonna House, had long felt a lack in the Latin Church and especially in North America of the deep awareness of the role of the Holy Spirit found in the Eastern tradition of her youth. When the first reports of the charismatic renewal began to appear in May, 1967, she was very interested. Early in 1968 she opened contacts with some of the leaders and asked Bishop J.R. Windle whether he would approve her inviting them to Combermere. He agreed readily and arrangements were made. ${ }^{9}$

Those who were present in Combermere for those days of teaching and prayer agree that it was a wonderful experience. They felt the power of the Spirit and the presence of Christ in a new way. They prayed in tongues and rejoiced to receive the Holy Spirit's gifts. And this was not just an experience of a couple of days; it stayed with them and became a normal and accepted part of their life.

This charismatic experience, appropriately called, in scriptural language, "the baptism in the Holy Spirit"' or, to avoid confusion with the Sacrament of Baptism, "the release of the Holy Spirit", is central

\footnotetext{
"There were usually Canadians attending Notre Dame, especially in the summer, and some of them joined the charismatic renewal as early as 1967 . We shall see below the case of Sister Flore Crête. In Regina, one of the first members in the prayer group in June 1969 had had "two years of experience from the pentecostal prayer groups of Ann Arbor and East Lansing"; this comes from the notes on the meeting of June 8, 1969, kept by Adrian Popovici.

${ }^{8}$ Descriptions of the group differ: one mentioned only Steve Clark and Jim Cavnar, another the same two plus two young women, and in a note about Father Duffy kept by Adrian Popovici it is said that there were "two carloads of young people from Ann Arbor."

${ }^{9}$ Reimers, God's Country, pp. 70-71.
} 
to the charismatic renewal. ${ }^{10}$ The experience is practically always described in terms of an awareness of the presence of Christ, but the ways in which this is felt and the effects of it vary so greatly that the total experience may be said to be unique to each individual. Awe, love, joy, peace, an overwhelming power, a sense of forgiveness, acceptance - these and many old similar words recur in people's description of their experience, with many shadings and in varying combinations. Some Pentecostal Churches make the gift of tongues. a sort of test of true baptism in the Holy Spirit, but in Catholic experience the effects are much more varied. Prayer in tongues is quite commonly found but such effects as peace of soul in the face of troubles, a hunger for and a new understanding of Scripture, a deeper appreciation of the sacraments, conversion of life, and others are also often experienced and are seen as signs of the Spirit's action.

In Combermere, many members of Madonna House found in this experience precisely the sort of unity with the others that Catherine Doherty had long been calling for among them, and in this unity they experienced also a new openness to others and an ability to exercise their ministries and use their gifts which they had not known before. Catherine encouraged them, but always in relation to the main purpose of Madonna House in service. The prayer life of the Community was affected, especially by the use of healing prayer. In their common prayer, however, since not everyone had taken up the charismatic forms, they were careful to maintain the bond of peace and did not use tongues as a normal part of their worship.

\footnotetext{
${ }^{10} \mathrm{~A}$ considerable literature on this has sprung up in recent years. The following are useful : Steve Clark, Baptized in the Spirit and Spiritual Gifts, Pecos, Dove Publications, 1976; Dorothy Ranaghan, "Baptism in the Holy Spirit", in Kevin and Dorothy Ranaghan, eds., As the Spirit Leads Us, Paramus, Paulist Press, 1971, pp. 4-16, and "Baptism in the Holy Spirit and Christian Spirituality", in the same volume, pp. 78-90; Donald L. Gelpi, Pentecostalism: A Theological Viewpoint, New York, Paulist Press, 1971; Theological and Pastoral Orientations on the Catholic Charismatic Renewal, prepared at Malines, Belgium, May 21-26, 1974, | Ann Arbor:] Word of Life, 1974; Kilian McDonnell, ed., The Holy Spirit and Power: The Catholic Charismatic Renewal, Garden City, Doubleday, 1975; James E. Byrne, Living in the Spirit: A Handbook on Catholic Charismatic Christianity, New York, Paulist Press, 1975, esp. pp. 1-28; Salvador Carillo Alday, "The Baptism in the Holy Spirit: Theological and Pastoral Questions", in Martin, ed., The Spirit and the Church, pp. 182-191, and Basil Pennington and Francis Sullivan, "The Baptism in the Holy Spirit and Christian Tradition", in the same volume, 192-198; George T. Montague, The Spirit and His Gifts, New York, Paulist Press, 1974.
} 
From 1968 to 1980 there was a Sunday evening prayer meeting at Madonna House. Some of the staff participated, but this was not really a continuing prayer group; rather it was a service offered to guests at the house. In 1980, they re-examined the place of the prayer meeting in their life and decided to drop it. It had never been central for the members of the community at Madonna House and its dropping did not mean a turning away from the charismatic experience which remains part of their life.

A significant distinction may be useful here. What can be seen at Combermere is a prolonged series of prayer meetings without the establishment of a prayer group. The meeting were an apostolic under taking of Madonna House offered to the guests who came there. The guests, coming and going, could benefit from the meetings, but they could not form a lasting group. That development, which would be so characteristic of the charismatic renewal, was still to come.

Madonna House never undertook any sort of systematic outreach in the charismatic renewal. Some members, however, notably Fathers Robert Wild and Francis Martin, ${ }^{11}$ have made significant contributions by their writings. And the initiative of one man provided the spark for the development of prayer groups elsewhere in Canada.

Among those for whom the visit of the people from Ann Arbor was a decisive moment was Father Jim Duffy. In October, 1968, he was sent to Marian Centre in Regina, and he went with the resolve that if he could find six people who wanted to pray he would get a prayer group started.

The staff at the Marian Centre were very busy. There could be no thought of gathering them into a weekly charismatic prayer group. Father Duffy pondered and prayed. On January 1, 1969, he gathered three other members of the staff plus a visiting priest for a first private meeting. There was a genuine desire among them for a session like that in Madonna House the previous summer, and afterwards there was agreement that another meeting should be held, but they were uncertain as to when this should be and decided to leave it up to the Holy Spirit. Actually the next meeting was not held until May 24, the Vigil of Pentecost. Again it was a private meeting, that is, held without

\footnotetext{
${ }^{11}$ Father Martin has been prominent in the renewal internationally. He has now left Madonna House and is teaching at the University of Steubenville, in Ohio.
} 
any open announcement or general invitation, but this time there were seven people there - Father Duffy had found his six others - and there was common agreement that another meeting should be held the next week and that it should be an open meeting at the Catholic Centre in Regina.

On June 8, 1969, then, nineteen people gathered at the Catholic Centre for the first open prayer meeting in Regina. Father Duffy explained the nature of such a meeting and they went on to pray and praise the Lord, with moments of silence and readings from Scripture. During the meeting Father Duffy asked the Lord to give a sign to show that these meetings were in accordance with his will. Later in the week, when the staff of the Marian Centre were on retreat, he felt moved to pray with one of them who then experienced the gift of tongues. This was at once seen as the sign that had been asked for. The group went on meeting week by week and grew slowly both in numbers and in the manifestation of gifts. They began to pray in tongues, then to sing praise in tongues, to speak in tongues with an interpretation, to pray for healing and to experience it. ${ }^{12}$

One of the aspects of any prayer group is the need to develop a committed nucleus which can carry the group through difficult times and provide a basis for growth. We can see this happening in Regina. During the first eight weeks (June 8 to August 3 ) forty-five names were recorded as having taken part in the group; of those, ten had attended at least four meetings. In eight weeks, in the spring (February 8 to March 29), sixty-five names were recorded and twenty people were there at least four times. The Madonna House community at Marian Centre helped to get the group started. Of the ten regulars during the first eight weeks, five were from there. But in order to take on a life of its own the group had to develop its own nucleus, and it did. Only Father Duffy and one other from Marian Centre were among the regulars in the later eight weeks, and the other was not one of those who had been there at the start. The people from Madonna House were, of course subject to transfer to new appointments; they also found it necessary, once the group got going, to limit their attendance in order to take care of other concerns of Marian Centre. On the other hand, four of the five regulars who were not from Marian Centre were still among the twenty regulars in the spring. By the spring the group had found its

\footnotetext{
${ }^{12}$ Father Duffy let me use his personal copy of his report to Archbishop O'Neill, "Regina Charismatic Renewal Prayer Group (Report from June 1, 1969, through August
} 
identity. At the end of January they had decided to establish a core group of about twelve people. The meeting of February 8 was the first at which the core acted as a team, and that marked the real beginning of growth. In the previous eight weeks the average size of a meeting had been just twelve, lower than the summer before; the eight weeks beginning February 8 averaged twenty-six, and the weeks after that jumped to about sixty. ${ }^{13}$ By the time Father Duffy was transferred from Regina to the West Indies in the fall of 1970 the group in Regina was well established.

Well before that, the renewal had begun to spread. In early July, 1969, when the Regina group was still in its infancy, Father Duffy went to Edmonton to give a retreat which soon became a charismatic experience. By the fall, a group was starting up at the Oblate Fathers' retreat house at St. Albert, north of Edmonton. This was charismatic, but somewhat muted in character, perhaps because of its situation. It closed down in 1970. Other groups started up and folded, but always started up again. By the summer of 1971 it was clear that the renewal was established in Edmonton. ${ }^{14}$

Opportunities for the spread of the renewal came especially from the work Father Duffy was invited to do with communities of Sisters. During 1970 he spoke on prayer and conducted prayer days with several particular communities and also with gatherings of Sisters from various groups. He worked with the Precious Blood Sisters, the Sisters of Sion, Sisters of Service, the Grey Nuns and the St. Joseph Sisters, but most of all with the Sisters of Charity of St. Louis. In December, 1969, he was asked to assist at the second session of the Chapter of Renewal of the Sisters of St. Louis at Radville, Saskatchewan. Out of this came

1, 1970)", 13 typed pages. Much of this is also contained in the notes of Adrian Popovici, along with a good deal of other material on the first years of the group in Regina.

${ }^{13}$ All of this is based on the notes preserved by Adrian Popovici. The notes on the meetings seem first to have been Father Duffy's work; they are continuous for the first eight meetings and stop after August 3, 1969, when he had to return to Madonna House for some time, then resume when he returned in November. On February 12, 1970, the core group asked Helen Stephenson to record the newcomers to each meeting. Full lists continued to be kept, with special notice of newcomers, until March 29; then, as numbers increased rapidly, only the new names were noted.

${ }^{14}$ Father Duffy's retreat in Edmonton was on July 2-8, 1969. His account of the experience is in Adrian Popovici's notes. The later developments are recounted by Cavan and Gerry Delvin, in Reimers, God's Country, pp. 39-41. 
an invitation for him to conduct a series of prayer days and retreats for the Sisters at centers throughout Western Canada, so that all the members of the community could hear him. This was carried out in January to April, 1970, and took him to Vancouver and Calgary as well as back to Regina and Radville. Vancouver was especially interesting. ${ }^{15}$

The charismatic renewal was already underway in Vancouver when Father Duffy went there in February for the first time. It was largely the result of the zcal of Rev. Bernice Girard, Pentecustal chaplain at the University of British Columbia. She had been interested in encouraging the Neo-Pentecostal Movement among Anglicans and others in Vancouver for some time, and when news broke about the beginnings of the Catholic charismatic renewal during the summer of 1967 she was very interested. In the spring of 1968 she organized an ecumenical conference of Pentecostals and Neo-Pentecostals to which she invited Kevin Ranaghan from Notre Dame. ${ }^{16}$ No lasting Catholic group seems to have come from that, although a number of Catholics began to participate in meetings run by Bernice Girard. A Catholic group started in the summer of 1969 in a bookstore run by Mary Kelly, at the initiative of Sister Barbara Ann Chase who had just come from Seattle to work at catechetics in Vancouver. After some weeks at the store, the group settled at the Cenacle Convent. ${ }^{17}$

Father Duffy's visits to Vancouver can serve to illustrate the character of the renewal there in early 1970 . He went there primarily to see the Sisters of St. Louis, but was also swept up into other activities. On the evening he first arrived, February 19, he was taken to one of Bernice Girard's meetings. The next two days were largely taken up with the Sisters. On the 22nd. Sunday, he was on an open line show

\footnotetext{
${ }^{15}$ Father Duffy's work with Sisters and his travels are outlined in his Report to Archbishop O'Neill, pp. 11-13. Special accounts of the retreat in Calgary, March 6-8, 1970, (the heading says February, but this seems to be an error) and the visit to Vancouver, February 19-24, 1970, (again the heading says 1969, which is clearly a slip), are in Adrian Popovici's notes.

${ }^{16}$ I should note, with praise to God, that this was my own first contact with the charismatic renewal. I was in Vancouver then, and Kevin Ranaghan stayed with us at St. Mark's College there. I have described my reactions and later development in "Basilians and the Charismatic Renewal: Some Personal Thoughts", The Basilian Newsletter, 1976, No. 18, November 17, pp. 1-15, esp. p. 4.

${ }^{17}$ Mary Kelly's account is in Reimers, God's Country, 37-39. She mentions a visit by Father Joe Kane, O.M.I., coming back from Spokane, where he had been studying, and celebrating a charismatic Mass in 1969. We shall see something of his role elsewhere.
} 
on radio with Bernice Girard. On Monday he was invited to the Precious Blood Sisters, who turned out to be intensely interested in the charismatic renewal. And that evening he was asked to lead a prayer meeting at St. Augustine's parish, conducted by the Oblate Fathers. He found about fifty people there, and a meeting filled with tongues and encouraging prophecy, but he felt they needed some instruction on the baptism in the Holy Spirit and the gifts. His sense of this need may have stemmed in part from his having had supper with the priest recently appointed as Chaplain to the charismatic renewal in Vancouver by a somewhat concerned Archbishop. His second visit, in April, was more of the same. Besides praying with the Sisters, he preached at Fraserview Assembly Church, was on the radio again, introduced as a Catholic Pentecostal priest, and took part in a prayer meeting at the Cenacle with about twenty-five, mostly young, people.

This development in Vancouver points to an aspect of the renewal which has provided some of its most remarkable achievements and also some of its striking failures. The charismatic renewal in the Catholic Church owes much to the Pentecostal and Neo-Pentecostal Movements which preceded it. The awareness of this debt and a good deal of shared experience has made possible a deeper ecumenical relationship than is commonly found. This must be seen as of great value and of great hope for the future, as a real sign of the action of the Spirit. But at the same time it certainly has posed dangers. Without a deepening, truly Catholic understanding of the experience, such ecumenical relations can be easily distorted. There have been cases of individuals and even of whole groups of Catholic charismatics abandoning the Church. As Father Duffy perceived, instruction is especially needed in this context.

While all this and much more was going on in Western Canada, the renewal was beginning elsewhere in the country as well. In Ontario, outside of Combermere, it is not easy to say with certainty where the first activity was. It may have been in Sault Ste. Marie at St. Mary's College in the fall of 1969. A group of women from there made a retreat in Michigan which turned out to be a sort of Life in the Spirit Seminar. Three of them, shortly after, received the gift of tongues. Wondering what to do, they contacted the retreat master, who put them in touch with a Sister in Sault Ste. Marie, Michigan. With her, they decided to form a prayer group at St. Mary's, where Father Ed O'Reilly, C.S.B. was interested. At the beginning the group was international in membership and met sometimes in Canada and sometimes in the United 
States. Then it settled down as simply a Canadian group for some years until recently when it has become international again. ${ }^{18}$

Windsor was another place where the beginnings were early, perhaps ahead of Sault Ste. Marie. It was probably the first place where a significant number of Canadian Catholics became involved in the renewal. Ann Arbor was only a few miles away, and there was a large early group at the Gesu parish, the Jesuit church in Detroit. Their influence was soon visibie in Windsor, but for quite a while there was little felt need for a distinct group in Windsor itself. Sometime in $1969, M^{r}$ and $M^{r s}$ Ed. Heisler began to hold a meeting in their home, the start of a group which, when it outgrew the house and moved to Holy Rosary Church, became known as the John XXIII Group. Other groups soon started, at St. Theresa's Church, Holy Redeemer College, Assumption Church and elsewhere. ${ }^{19}$

In Toronto, during the fall, winter and spring of 1969-70, a number of people who had made one of the Faith and Sharing retreats organized by Jean Vanier, gathered each Friday evening at St. Augustine's Seminary for follow-up sessions of Scripture study and sharing. The combination of this with the influence of the Full Gospel Business Men's Fellowship provided the rather unlikely background for the emergence of two charismatic groups in 1970.

The sessions at St. Augustine's were usually led by two seminarians, Jim Hanna and Don Lizzotti, who had been to the Full Gospel Business Men's meetings. The others found their style of prayer puzzling but attractive, and some of them also went to the Full Gospel meetings. In May, 1970, the organizers of the Vanier sessions decided to suspend operations until September. Some of those who had been attending, however, were unwilling to give up meeting and arranged to continue on Thursday evenings at a private home. By the end of the summer, the meeting, still led by Don Lizzotti, had become a clearly charismatic group and had outgrown the space of a private home. At one meeting

\footnotetext{
${ }^{18} \mathrm{My}$ information about this group comes from Father Ed O'Reilly. I have also visited this group fairly often since about 1970 .

${ }^{19}$ See the comments of Bruce McLeod in Reimers, God's Country, pp. 74-75. See also Father George Kosicki's account of his own experience in the renewal in Windsor in 1968-70, "A Broken Cedar", in Ralph Martin, comp., New Wine, New Skins, New York, Paulist Press, 1976, pp. 67-77. My own first prayer meeting came in December, 1969, or January, 1970, when I was visiting the Basilians at Assumption University; George Kosicki and I went to Ann Arbor.
} 
they had eighty-five people jammed into every available nook and cranny. Most of them moved to a day nursery run by the Sisters of the Immaculate Conception to become the Emmanuel Prayer Group. After two years that space, too, became too small and the group finally settled in the basement of St. Basil's Church. ${ }^{20}$

At the time the move was being made to the day nursery, one couple, Orval and Margaret Mooney, decided that they should try to start a group in their parish, Holy Rosary. This had been in their hearts for some time. Earlier in the year, while the Vanier sessions were still on, they had arranged for Kevin Ranaghan to speak at Holy Rosary ${ }^{21}$ and he had encouraged them to think of a parish group which would be specifically Catholic in character. In September they invited Father George Kosicki to help persuade the priests of the parish, his Basilian confreres, that the idea should be accepted. And with Father John Gaughan, then the Treasurer General of the Basilians, they worked out a format for a prayer meeting centered on the Eucharist. ${ }^{22}$ From Emmanuel and Holy Rosary many other groups sprang up in the city.

In Ontario, there was no one figure that played anything like the role that Father Duffy had played in the West. The general picture that emerges from the groups in Sault Ste. Marie, Windsor and Toronto, and from many others that could be cited, ${ }^{23}$ is one of great variety. This is true everywhere, of course, and it is one of the signs that this really is the work of the Holy Spirit - the Spirit of God deeply respects our human spirits, and when he touches us he does so in precisely the way we need, the way which will best enable us to respond in full freedom, and this can be seen in the development of groups as well as of persons - but it can perhaps be seen best in Ontario. Each group started in its own way, with its own background, and as the renewal spread the various influences balanced and reinforced one another.

In Quebec, the first French-speaking group was that started by Sister Flore Crête in Montreal. A Sister of Providence, she was studying in

\footnotetext{
${ }^{20}$ Vince Kolycius, “In the Beginning”, The Rising Light, $1: 1$, May, 1977, pp. 9-11.

${ }^{21}$ For one outside reaction to this talk see Jerry Kienapple's statement in Reimers, God's Country, pp. 71-73.

${ }^{22}$ For several years Holy Rosary Prayer Group was my group. I must express my thanks to Orval and Margaret Mooney not only for specific information for this paper but especially for their friendship and prayerful support over the years.

${ }^{23}$ See the accounts of Audrey Guillet and Sister Gwyneth Roberts concerning Ottawa in Reimers, God's Country, pp. 78-81.
} 
Notre Dame in 1967 when the renewal started up there. When she returned home in 1969, she wanted to get a group started. Her superiors objected to her starting one in the motherhouse, so she began in a very small way in her family home. ${ }^{24}$

Greater impetus came the following year with the return to Quebec of Father Jean-Paul Regimbal, a Trinitarian, who had been introduced to the renewal in Phoenix, Arizona, where he had been sent for reasons of heaith. A wide-ranging apostolate soon developed from his experience there and his health improved enough that his superior called him home in 1970 and named him Director of a retreat house in Granby, Quebec. $\mathrm{He}$ at once began to bring a charismatic influence into the retreats. People were healed, and soon hundreds of people were coming and groups were starting up. ${ }^{25}$

The English-speaking renewal in Quebec started with the arrival of Father Joe Kane, O.M.I., in 1970. Having had some time as a missionary in Peru, he had returned for a break and while taking a refresher course had found the renewal in Seattle, Washington. He was influential in the early development of charismatic activity in Vancouver, ${ }^{26}$ and then came to Montreal. His work there quickly led to the involvement of other priests, Oblates and diocesan, and the foundation of several groups. ${ }^{27}$

Two features of the renewal in Quebec, which can be seen in these beginning and in later developments, should be mentioned here. One of them is somewhat different from experience elsewhere, while the other is a common feature but especially striking in Quebec.

The first is the very significant role of priests in the renewal in Quebec. At the beginning there was controversy. This is hardly surprising. The cultural forms of Pentecostal piety had been alien to Catholics everywhere, but in Quebec a double sort of translation was needed. There was a great sensitivity in Quebec, as the Seventies were beginning,

\footnotetext{
${ }^{24}$ Peter E. Prosser, "An Historical and Theological Evaluation of the Charismatic Renewal," unpublished Master's thesis, University of Montreal, 1978, cited in Reimer's God's Country, pp. 122-123.

${ }^{25}$ Prosser, Evaluation, cited in Reimers, God's Country, pp. 123-124, and Jean-Paul Regimbal's own account, ibid, pp. 125-126.

${ }^{26}$ Statement of Mary Kelly in Reimers, God's Country, pp. 37-39.

${ }^{27}$ Prosser, Evaluation, cited in Reimers, God's Country, p. 123.
} 
to the threat posed by the dominant English-speaking culture of the continent. The renewal could be seen as part of that threat. And many in the Church were very much aware of the dangers of the vagaries of new doctrines and forms of worship in the Church. For some, Jean-Paul Regimbal embodied these dangers. He was denounced to the Archbishop of Sherbrooke, and while that in itself was soon settled a shadow remained. Here, one might say was the temptation which Ronald Knox had seen as characteristic of movements of religious enthusiasm and experience, which those who had gone through it could only see as the power of God in their lives, was being challenged and questioned by those in authority in the Church, and the temptation was to proclaim the experience by denying the authority. ${ }^{28}$ But the response of the leaders of the renewal in Quebec was an ecclesial one. They requested and received permission from Archbishop Paul Gregoire of Montreal to hold a seminar at the Grand Seminary in Montreal especially for priests and religious to provide them with information about the charismatic renewal, its history, the experience involved and its developing theology. Called in this way to understanding and to leadership, the priests responded vigorously. Within six months after the sessions held at the beginning of September, 1972, the numbers of people involved in the renewal doubled. ${ }^{29}$

This development is significant especially because one of the important aspects of the renewal has been the effective lay leadership it has called forth. In fact, in the rest of Canada, one of the problems faced by the renewal has been a lack of priests willing to become involved. This has often left people who were hungry for Catholic teaching without any voice able to speak to them in the name of the Church, and has sometimes led to a gap between the experience of prayer and the sacramental life of the Church. Priests, on the other hand, have often found it difficult to know how to respond to a lay leadership strong in the experience of prayer, rooted in the word of God and filled with a deep pastoral concern for their groups, but lacking instruction in and understanding of precisely those aspects of the Church's teaching and practice that priests have been taught to emphasize. The

\footnotetext{
${ }^{28}$ R.A. Knox, Enthusiasm : A Chapter in the History of Religion, Oxford, Clarendon Press, 1950, pp. 1-4, 584-590. For a good treatment of the Catholic charismatic renewal in relation to Knox's work, see Alan Schreck, Ronald Knox's Theory of Enthusiasm and its Application to the Catholic Charismatic Renewal, unpublished Ph. D. thesis, Toronto : University of St. Michael's College, 1979.

${ }^{29}$ Prosser, Evaluation, cited in Reimers, God's Country, pp. 123-124.
} 
relation of priest and lay leader is a delicate and demanding one on both sides, one which must be founded on a deep love and mutual respect. When, as sometimes happens, it turns into a competition for power, this must be seen as a failure. Rather, this relation needs to be seen as a powerful call of the Holy Spirit to the whole Church to grow in unity and in true community. Such community is not a univocal reality and it is not surprising that the Spirit's call has found a somewhat different response in the Church in Quebec than in the rest of Canada.

The second aspect of the development of the renewal in Quebec is its rapid growth. This has been true elsewhere in Canada and, indeed, world-wide, but has not always been as explosive or as visible as in Quebec. At the beginning of 1973 only eighteen groups were known in Quebec, six English-speaking and twelve French-speaking. By the time of the bi-lingual conference held at Loyola that summer there were fifty groups; 4,000 attended the conference. One year later an entirely French-speaking conference in Quebec City drew 6,500 and 400 groups existed. In 1977 about 40,000 gathered in the Olympic Stadium in Montreal for the closing session of a conference, with about half of them probably to be counted as actively involved in the renewal. By 1979 there were some 822 groups in the province with a membership of over $38,000 .{ }^{30}$

This rapid growth has been attributed to the sort of changes which had been taking place in the society and church of Quebec during the Sixties and Seventies. Before the Second Vatican Council, Quebec had begun its own Quiet Revolution. Schools and hospitals and other social services had been, if not exactly secularized, at least thoroughly democratized. A clear pattern of life characteristic of a rural and religious society shifted and changed; the clerically dominated cultural monolith that had been perceived as Quebec gave way to a sort of secular pluralism. Religious practice fell dramatically. Then came the renewal, and it has been argued that

the charismatic conversion, working within a framework in which the Church has lost a major part of its power to control and to constrain, enabled a body, which had been held down, to pull itself together, recognize its own reality and become free. ${ }^{31}$

\footnotetext{
${ }^{30}$ Ronald Chagnon, Les Charismatiques au Québec, Montreal, Quebec/Amerique, 1979, p. 11.

${ }^{31}$ Chagnon. Les Charismatiques, 103 (my translation). For a similar picture, from a different point of view, see Julien Harvey. "The Canadian Church in 1980, French Section". in Religious in the Local Church, Ottawa. Canadian Religious Conference, 1981. pp. 229-232.
} 
It is always a mistake, however, to attribute too much influence to particular causes in order to explain an event which is much broader. By 1979 there were probably about 500 prayer groups outside of Quebec with some 20,000 members. ${ }^{32}$ In proportion to the Catholic population that is not much different from the experience of Quebec, but less visible because so widely spread.

In Atlantic Canada the renewal started in the summer of 1970 in both Cape Breton and Price Edward Island. Father John McLeod, who was the pastor of New Waterford in Cape Breton visited Ann Arbor and returned to start a group in his parish. ${ }^{33}$ At about the same time Fathers Joe Kane and Fred Miller, O.M.I., gave a retreat to the Sisters of St. Martha in Charlottetown. They offered an ecumenical session for the clergy and opened their evening services to clergy and laity. Among those who attended were Father Faber MacDonald, now Bishop of Grand Falls, Newfoundland, and Father Gerry Tingley. ${ }^{34}$

In 1971, in Halifax, some people who wanted to learn to pray went to ask Archbishop Hayes for help. By that time he had heard of developments in Charlottetown, so he invited Fathers Faber MacDonald, Gerry Tingley and Ted Butler to Halifax to meet with some people at his residence. A small group then began to meet at each other's homes until they moved to St. Thomas Aquinas Church. ${ }^{35}$

In the fall of 1973, beginnings were made in Newfoundland and New Brunswick. A leadership session was held in Charlottetown and Father Phil Lewis came from Newfoundland to see what was going on. He went back to start a group in his parish in Freshwater, near Placentia. ${ }^{36}$ In Saint John, New Brunswick, Father Bill Comerford,

\footnotetext{
32 There is no common count, so this is just an estimate. Ontario had 212 groups with over 11,000 members; Directory, Ontario Catholic Charismatic Prayer Groups, Ancaster, Bread of Life Press, 1979.

${ }^{33}$ Father Gerry Tingley was very helpful in supplying information about Atlantic Canada. See Brother Karel Frankemolle in Reimers, God's Country, pp. 133-134.

${ }^{34}$ Father Gerald Tingley, in Reimers, God's Country, pp. 15-17.

${ }^{35}$ Archbishop James Hayes, in Reimers, God's Country, pp. 135-137. I must also thank Archbishop Hayes for giving me information in person. See also Dr. Bob Brown and Mildred Moir, in Reimers, God's Country, pp. 137-138.

${ }^{36}$ Sister Teresa Antle, Marion Counsel and Betty Prowse, and Father Phil Lewis, in Reimers, God's Country, pp. 141-145.
} 
C.Ss.R., had invited Faber MacDonald and Gerry Tingley from Prince Edward Island, and from that came the first English-speaking group in New Brunswick. In November, 1973, Father Oscar Melanson started a French-speaking group at the Maison Ste. Croix in St. Joseph, New Brunswick. ${ }^{37}$

Again we may glance at a couple of features of the renewal in Atlantic Canada. One has to do with structures and represents a common problem and development. The other is the involvement of Bishops in the renewal; this may be seen as remarkable to begin with, but becoming more common.

The renewal has been remarkably free from structures. It has recognized the authority of the Bishops, but apart from that no one really has any sort of effective control beyond the limits of a local group. Still, some sort of structure is needed to arrange conferences and to provide leadership in other ways. The leadership session held in Charlottetown in 1973 was intented to lead to the formation of an Atlantic Pastoral Committee. One was formed, but was allowed to drop the following year when it became obvious that the concept was not generally acceptable. In 1976, another leadership meeting at Halifax led to the founding of the Atlantic Service Committee, the change of title being expressive of a somewhat diminished role. This Committee has organized conferences at Charlottetown, Halifax, Moncton, St. John's, Antigonish and Sackville. ${ }^{38}$ Similar structures exist in the Western.Provinces, Ontario and Quebec, with the latter one probably exercising the most directive role.

Archbishop James Hayes of Halifax is the only Canadian Bishop to have been personally involved in the initiation of the renewal in his diocese. When he attended the 1972 International Conference at Notre Dame, he was one of only three bishops present. Since that time, one of the notable features of the renewal in Canada has been the active interest and involvement in it of the bishops of all regions. They are present in numbers at every regional conference, and have not hesitated to speak out in support of the renewal. In April, 1975, the Canadian Bishops issued a message on the charismatic renewal addressed to all Canadian Catholics. This was extraordinary not only in its solemn character, being the common statement of all the bishops rather than

\footnotetext{
${ }^{37}$ Père Oscar Melanson, in Reimers, God's Country, p. 141.

${ }^{38}$ Thanks again to Father Gerry Tingley.
} 
merely a document of some commission or committee, but also in the way in which the bishops spoke in favor of the renewal and at the same time pointed out some negative aspects with a voice that seemed to come from within the renewal itself rather than from the sort of prudent distance adopted by most such statements down to that time. ${ }^{39}$ In this, the statement of the Canadian Bishops differed from those of their American brothers in 1969 and later in 1975, both of which were more cautious and reserved, ${ }^{40}$ and differed, indeed, from the statement some of their own number had issued the previous year. ${ }^{41}$

The charismatic renewal in the Catholic Church in Canada is still a very recent phenomenon. I have no doubt that it is a work of the Holy Spirit for the renewal of the Church, but for the final effects of such action we must wait with patience and acceptance upon the Lord. I have tried to give an account of the origins of the renewal and to touch on some significant features. Many aspects have, perforce, been left undeveloped. Such a development as the formation of covenant communities is obviously important, but it has seemed to me at once too complex and too recent to be taken up here.

In some areas of the country active membership in the renewal seems to have declined in the past few years. In others it has just about held steady. And in some it is still growing rapidly. Many of the leaders have expressed concern about such aspects as the need for sound teaching, the slowness of new leaders in emerging and especially the frustration of the 'swinging door syndrome'. It is easy to understand such concerns; yet it seems to me important not to exaggerate them. There are probably about 60000 Canadian Catholics now actively involved in prayer groups while perhaps the total who have been so involved over the time since the renewal began here would be five times that many or more. That is the result of the 'swinging door'; but should this be seen mainly as a matter for concern or as a reason for praising God? In its own best self-understanding, the charismatic renewal has always seen itself not as a movement destined to grow ever stronger

\footnotetext{
${ }^{39}$ Kilian McDonnell, ed., Presence, Power, Praise: Documents on the Charismatic Renewal, Three Vols, Collegeville: The Liturgical Press, 1980, 2: pp. 86-98, and esp. the introduction to the Canadian statement, 2: pp. 84-85.

${ }^{40}$ McDonnell, Presence, 1 : pp. 207-210, 2: pp. 104-114.

${ }^{41}$ McDonnell, Presence, 1: pp. 580-584; "Message of the Bishops of the Western Province of Quebec on the Catholic Charismatic Renewal".
} 
and clearer in its own self-identity but as a weak instrument chosen by God to be filled with his power in order to bring about, and to disappear before, the renewal of the whole Church. In this context the 'swinging door' may come to be seen as moved by the wind of the Holy Spirit. In any case full renewal is still to be achieved and we can only pray to the Father, through his Son, Jesus Christ our Lord, to let his Spirit come now, with a mighty wind and tongues of fire, as at a New Pentecost. 